\title{
Technological Capability and Firm Performance
}

\author{
Fernanda Maciel Reichert', Paulo Antônio Zawislak²
}

\begin{abstract}
This research aims to investigate the relationship between investments in technological capability and economic performance in Brazilian firms. Based on economic development theory and on developed countries history, it is assumed that this relationship is positive. Through key indicators, I33 Brazilian firms have been analyzed. Given the economic circumstances of an emerging economy, which the majority of businesses are primarily based on low and medium-lowtechnology industries, it is not possible to affirm the existence of a positive relation between technological capability and firm performance. There are other elements that allow firms to achieve such results. Firms of lower technological intensity industries performed above average in the economic performance indicators, adversely, they invested below average in technological capability. These findings do not diminish the merit of firms' and country's success. They in fact confirm a historical tradition of a country that concentrates its efforts on basic industries.
\end{abstract}

Keywords: technological capability; firm economic performance; emerging economy; low-technology intensity

\footnotetext{
1,2 Innovation Research Center, Management School, Federal University of Rio Grande do Sul, Brazil, Washington Luiz, 855 - Porto Alegre. Brazil.

E-mail: fernandareichert@gmail.com, ${ }^{2}$ e-mail: paulo.zawislak@ufrgs.br
}

ISSN: 07 I8-2724. (http://www.jotmi.org) 


\section{Introduction}

Joseph Schumpeter, in 1911, has already recognized the relationship between economic development and technical progress. These concepts underpin the economic development based on innovation. It is from the relationship between knowledge and development, that we assume there is a positive relationship between technological capability and economic performance. Therefore, if we consider that, to profit, a firm needs a capability to innovate, the more firms invest in their technological capability, the greater its performance should be.

Years have shown that this relationship is often positive in developed countries. However, between 2000 and 2010 Brazilian GDP grew more than $200 \%$, even though its economy is based on low and medium-low-technology industries (as OECD, 201 I classification). Industrial sectors such as these tend to invest less in their technological capability. Nevertheless, Brazilian companies like Petrobras (petroleum product), Vale (basic metals) and Ambev (beverages), besides being industry and national leaders, represented the biggest revenues among Brazilian industrial firms, between 2008 and 2010 .

One question, thus, arise: how can a low or medium-lowtech company achieve positive economic performance? This picture indicates that, besides investing in technological capability, there should be other means for lower technological intensity firms to reach competitiveness.

Given this context, we aim to answer the following question: what is the relationship between technological capability and firm performance in Brazilian firms? By answering that we may contribute to understand of this relationship in an emerging economy scenario, where most industrial companies are traditionally operations based.

This paper is organized in a way as to give a background of technological capability and firm performance, as well as their relationship, and to present the indicators used to measure both constructs. Following that, we present the method used in this research, and then, data is analyzed and results are discussed to, finally, make our final remarks on this research.

\section{Technological capability and firm performance}

During the 1990s, different studies focused on firm technological capability issues (Lall, 1992; Bell and Pavitt, 1995; Archibugi and Pianta, 1996; Panda and Ramanathan, 1996; Kim, 1999). Both theoretical and empirical studies had deepened the research on this subject. Furthermore, new insights started to address the relationship between technological capability and firms' successful performance (Hall and Bagchi-Sem, 2002; Garcia-Muiña and Navas-López, 2007; Jin and Von Zedtwitz, 2008; Figueiredo, 2009).

Skills, knowledge and experience are required to operate existing systems and to generate technical change from technological capability. Lall (1992) sees technological capability as a continuous process to absorb and to create technological knowledge from the interaction with the environment and the accumulation of skills and knowledge mastered by a firm. Bell and Pavitt (1995) understand that efficiency is not only affected by external technology acquisition, but also should consider the ability to manage internal changes in technologies used in the production.

Firms need, in fact, to accumulate resources and competences, which allow them to have a more developed technological capability than their competitors. In that sense, technological capability relates to absorption and transformation of a technology as a way of reaching higher levels of technical-economic efficiency (Zawislak, et.al., 20 I2; Ruffoni, et.al., 2012).

Many authors link technological capability to firm knowledge (Panda and Ramanathan, 1996; Garcia-Muiña and NavasLópez, 2007; Jin and Von Zedtwitz, 2008). For Pavitt (1998), firms develop their technological capability in an incremental way, and in doing that, they are limited to continue to do what they already know, which means there is a cognitive limit to what a firm is capable of doing. In sum, the concept of technological capability embraces the generation of new knowledge and learning.

Calantone, Cavusgil and Zhao (2002), say that learning leads a firm to innovate, which affects its performance.Accordingly, they argue that firms need to focus on learning process to obtain competitive advantage in the market. For Sirmon, Hitt and Ireland (2007: 277), firms' ability to leveraging relates to its "capability to create value for customers and wealth for owners".

In this study, we understand technological capability as the firm's ability, based on its accrued knowledge, to perform a set of activities, which results in new technological knowledge development to achieve positive economic results.

ISSN: 07I 8-2724. (http://www.jotmi.org) 
What defines firm's performance may vary, and depends on what its goal is and the context in which it operates. With the rise of information technology and the consequent globalization of markets, companies seek competitiveness through technological and organizational innovations (Tigre, 1998). Thus, evolutionary theories of the firm (Nelson and Winter, 1982) got stronger and therefore, technological change has become a major concern within firms.

In a constantly changing context, firms should focus on their internal performance and also pay attention to the market. Technical knowledge must be sold or somehow used in the market to generate higher profits (Teece, 1986).

Many authors believe that economic gains arising from technical change and firms' performance are, in fact, the result of innovations. Dosi (1988) emphasizes the importance of economic returns arising from activities such as exploration and development of new products and new production techniques when a firm believes there is a market for its new products and processes. Pavitt (1998) said it is important to apply knowledge into commercially successful innovation, therefore, a firm with good performance is a firm that achieves competitive advantages. Tsai (2004) argues that a firm with a faster product development process than its competition can get first in the market and ensure good economic returns.

Firms innovate because they expect to obtain economic benefits with it. Often this profit does not come from launching brand new products. It can actually come incrementally, from adjustments in production process, in organizational structure or even from marketing actions. They all allow for higher margins.

The understanding of the firm performance evolves, along with the relationship of its technological capabilities, with the society development. While society was simpler, performance was related to cost reductions and higher profits. As society become more and more complex, firms as a way to keep their business up and running, must also evolve.
By analyzing the relationship between R\&D and productivity, Griliches (1998) considers the role of R\&D as an input to the productivity growth process. His main research result indicates that research and development positively contribute to general productivity growth. Authors studying technological innovation capability impact on Chinese firms' performance found that, although small, there is a significant relationship between R\&D investments and performance indicators (Yam, et.al., 2004). Wang (2007: 356) states that "new knowledge and new technology generated from R\&D activities increase productivity, not only at the firm level, but also at the industry and national levels." In studying relationship between R\&D and market value in developed countries, Ehie and Olibe (2010) understood that successful investments in R\&D result in innovative products and services that enable a company to improve its intangible assets. They concluded that investments in R\&D positively affect firm performance.

Besides some specific findings, most of these studies indicate, in one way or another, that there is a positive relationship between technological capability and firm performance. These findings reinforce the assumption that the greater are the investments in technological capability, the better the economic performance of firms is. The question is whether this assumption is valid in an economy like Brazil, which is traditionally more operational than technological.

\section{Measuring technological capability and firm performance}

To better understand the aforementioned relationship between technology and development, both in company and national levels, we should make use of empirical data. Studies that aim to measure firm performance as a result of its technological capability often use R\&D investments and number of patents registered by the firm (Hall and BagchiSen, 2002;Tsai, 2004; Coombs and Bierly, 2006; Garcia-Muiña and Navas-López, 2007).

Performance has been commonly assessed through traditional financial measures, internal efficiency, or market performance. The reviewed authors mentioned around 90 technological capability elements. The most frequent approach is in relation to research and development activities and to patent registration. Table I sums up these works. 


\begin{tabular}{|c|c|}
\hline Element & Basis for technological capability indicators \\
\hline$R \& D$ & $\begin{array}{l}\text { Resources allocation to R\&D (Archibugi and Pianta, 1996; Kim, 1999;Tsai, 2004; Figueiredo, 2009) } \\
\text { Average R\&D investment as \% of sales (Madanmohan, Kumar, and Kumar, 2004) } \\
\text { R\&D intensity (the ratio of R\&D expenditure and sales) (Coombs and Bierly, 2006; Hall and Bagc- } \\
\text { hi-Sen, 2002) } \\
\text { R\&D for product specification (Bell and Pavitt, 1995) } \\
\text { Cooperative R\&D (Lall, I992; Jin and Von Zedtwitz, 2008) } \\
\text { Basic research (Lall, I 1992) } \\
\text { Development of new technologies through partnerships (Bell and Pavitt, I995) } \\
\text { Projects of R\&D (Panda and Ramanathan, I996) } \\
\text { Conduction of R\&D activities (Archibugi and Pianta, 1996; Jin and Von Zedtwitz, 2008) } \\
\text { Existence of an R\&D department (Kim, I999) } \\
\text { R\&D capability (Yam et al., 2004) } \\
\text { Efforts in R\&D (internal R\&D, cooperative R\&D and technology import) (Tsai, 2004) } \\
\text { Existence of R\&D centers which have a partnership with research institutes (Figueiredo, 2009) }\end{array}$ \\
\hline Patent & $\begin{array}{l}\text { Number of patents (Archibugi and Pianta, 1996;Tsai, 2004; Coombs and Bierly, 2006; Figueiredo, } \\
\text { 2009) } \\
\text { Patent applications (domestic and international) (Hall and Bagchi-Sen, 2002) } \\
\text { Patent approval (domestic and international) (Hall and Bagchi-Sen, 2002) } \\
\text { Patent impact (measured by average citations that patents received) (Coombs and Bierly, 2006) } \\
\text { Technology cycle time (average number of years that the patent was prominently cited) (Coombs } \\
\text { and Bierly, 2006) } \\
\text { Scientific relationship (patent citation in scientific articles) (Coombs and Bierly, 2006) } \\
\text { Relationship between patent indicator and its impact (Coombs and Bierly, 2006) } \\
\text { Total scientific relationships of the firm's patents (Coombs and Bierly, 2006) } \\
\text { Local property right of a product (Jin andVon Zedtwitz, 2008) }\end{array}$ \\
\hline
\end{tabular}

Table I - Basis for technological capability indicators 
Firm performance may be measured by different indicators, such as internal measures of efficiency and productivity, outcome measures like profit, marketing measures such as market share. Despite the variety of indicators used by these authors to evaluate firm performance, we highlight two main groups of measures: results and market. For both, these elements can be measured through financial or other alternative indicators. Some other authors (Guan, et.al., 2006; Coombs and Bierly, 2006; Choi and Jong, 2010) indicate the importance of using multiple measures to assess firm performance as opposed to solely financial or market indicators.

\section{I.Technological Capability and Firm Performance Indicators}

It is assumed that the effective use of resources reflects in positive results for the firm. In this sense, investments in technological capability allow a firm to obtain positive economic performance. From this, we sought to identify which are the most significant indicators of technological capability and firm performance that can be identified through the reports released by companies. Table 3 shows the indicators used in this research.

Therefore, to evaluate economic performance of Brazilian firms, we selected indicators that: covered the two major groups identified, could be measured financially, and were available in the companies' reports. Table 2 sums up these measures.

\begin{tabular}{|l|l|}
\hline Element & Basis for firm performance indicators \\
\hline Sales & $\begin{array}{l}\text { ROS (Return on Sales) (Calantone, Cavusgil and Zhao, 2002; Coombs and Bierly, 2006; Dehning, Richardson } \\
\text { and Zmud, 2007) } \\
\text { Sales growth (Schoenecker and Swanson, 2002;Yam et al., 2004; Coombs and Bierly, 2006; Guan et al., 2006; } \\
\text { Artz et al., 20 I0) } \\
\text { Total revenue (Hall and Bagchi-Sen, 2002) }\end{array}$ \\
\hline Profit & $\begin{array}{l}\text { Overall profitability (Calantone, Cavusgil and Zhao, 2002) } \\
\text { Growth rate of profitability (Choi and Jong, 20I0) } \\
\text { Greater profitability than competitors (Isobe, Makino and Montgomery, 2008) } \\
\text { EBITDA (Earnings Before Interest, Taxes, Depreciation and Amortization) (Bellinghini and Figueiredo, 2006) } \\
\text { Percentage of profit growth (Guan et al., 2006) } \\
\text { EVA (Economic Value Added) (Coombs and Bierly, 2006) }\end{array}$ \\
\hline Market & $\begin{array}{l}\text { IPO (Initial Public Offering) (De Carolis and Deeds, 1999) } \\
\text { MV (Market Value) (Coombs and Bierly, 2006) } \\
\text { MVA (Market Value Added) (Coombs and Bierly, 2006) }\end{array}$ \\
\hline
\end{tabular}

Table 2 - Basis for firm performance indicators

\begin{tabular}{|l|l|}
\hline Technological capability elements & Technological capability indicators \\
\hline R\&D & $\begin{array}{l}\text { Existence of R\&D activities } \\
\text { R\&D Investment per year }\end{array}$ \\
\hline Patent & Number of patents registered per year \\
\hline Firm performance elements & Firm performance indicators \\
\hline Sales & Net Sales per year and Net Sales Growth \\
\hline Profit & EBITDA per year and EBITDA Growth \\
\hline Market & $\begin{array}{l}\text { Stock Price (in the last sale of each year), measured by the price percentage } \\
\text { variation and Stock Price Growth }\end{array}$ \\
\hline
\end{tabular}

Table 3 - Technological capability and firm performance indicators 


\section{Method}

To understand the relationship between technological capability and firm performance in and emerging economy, we analyzed I 33 Brazilian industrial firms that were listed in the major national stock market (BM\&FBovespa) between 2008 and 2010. We chose listed firms because they are required to inform their results, to follow the same data presentation standard, and they have a market indicator which can be measured (stock price).

In 20I I, 5 I8 companies were listed in BM\&FBovespa (20I I), however, because we limited our research to industrial firms, we had 169 firms. We have also excluded companies that, besides being industrial, are focused in services, for example, transportation services, sales of machinery and equipment, and telecoms. In addition, there has been exclusions of foreign companies that have consolidated data in their country of origin; companies that had no operations or had their operations halted in one or more years of the analyzed period, or capital was closed until a closing date of that period; cases where there has been a merger between companies in situations where their data was computed by another company, or when data from groups of companies are presented only consolidated; and companies that are no longer listed in BM\&FBovespa and for this reason their historical data are no longer available. After all exclusions, our final sample was I33 industrial firms. Appendix I shows how these companies are classified by BM\&FBovespa according to their industrial sector.

We collected secondary data through these companies' annual reports and profit and loss statements, their websites, and through data released by the BM\&FBovespa. Data was analyzed for the years 2008, 2009 and 2010. The data collection procedure at this stage was documentary research.

Information on patents number was collected on INPI - National Institute of Intellectual Property (INPI, 20II) website. Data on R\&D investment is not always available, as its report is not a requirement. When we decided to carry out this research, we expected that the economic information and technological capability were available in the documents provided by these companies.
However, unlike developed countries such as the United States, it is not mandatory in Brazil to disclose investments made in R\&D by public companies. Thus, a very small number of companies spontaneously detailed that data in their reports. Many companies have merged these data with other investments, for example, the expansion of productive capacity. For those companies that did not release that information, we contacted them by telephone. Since it was difficult to get information on R\&D investments, differently from all other indicators used $(n=133)$, the sample was smaller $(n=38)$. Even though the response rate was low, we used this indicator in our analysis. Hair et al. (2005), say the sample is considered small if it is equal or less than 30 . Hall and Bagchi-Sen (2002) considered the cutoff even lower. For them, the significance test is invalidated for ' $n$ ' smaller than five. These authors have also analyzed their results using different ' $n$ ' values, such as here, where we work with values of 38 and 133 .

Data was analyzed through SPSS - Statistical Package for the Social Sciences software. Statistical tests were performed with 133 companies, respecting, for each indicator, the total valid responses. For data analysis we performed the following statistical tests: frequency tests, descriptive statistics (minimum, maximum, mean and standard deviation), mean comparison T test, analysis of variance ANOVA and Pearson bivariate correlation.

\section{Results analysis}

In this section we analyze technological capability and firm performance indicators results. First, we build an industry profile, then we discuss the technological capability indicators, so we can finally analyze their relationship with firm performance indicators. 


\section{I. Industry Profile}

Bovespa Index is the most important indicator of share prices of Brazilian stock market (BM\&FBovespa, 20I2). For this reason, we used it to compare individual shares performance between firms in the sample. The 133 firms analyzed are classified into seven major sectors, according to BM\&FBovespa (20II): Industrial Goods, Construction and Transportation, Cyclical Goods, Non-Cyclical Goods, Basic Materials, Oil, Gas and Biofuel, and Information Technology (IT) (Appendix I). In order to contextualize the complexity with which these sectors deal in their daily production, and thereby to understand their results, we used technological intensity classification, according to the Organization for Economic Cooperation and Development - OECD (OECD, $20 \mathrm{II})$. Firms in the sample are predominantly (68\%) of low and medium-low-technology, which is a representation of a country that is historically operational. Table 4 shows how firms are classified according to OECD (20I I) classification.
Cyclical and non-cyclical goods industries stand out as the ones that best represent the national economy.They are large sectors formed by intensive labor manufacturing companies such as footwear, and by companies of agricultural sectors, like food and tobacco production. Moreover, the minority of companies is classified as high-tech, represented here by computers and equipment, aviation, hospital equipment and medication industries. It is noteworthy, however, that the highest operating profit (EBITDA in relation to net sales) and the highest net sales growth between 2008 and 2010 came from industries of medium-low and low-technology.

Results like these suggest that companies not necessarily need to be high-tech to obtain good results, at least in an emerging country context. Table 5 brings the results of the indicators, by technological intensity classification. It shows that sectors that have excelled in their economic performance are mainly medium-low and low-tech. These industries did not invest above average in R\&D. In addition, the main high-tech sector, IT, invested above average in R\&D but has, in general, underperformed. We have also observed that although all industries have increased their share prices between 2008 and 2010, high-techs were the only ones that have grown less than Bovespa Index average. Data like these, once again, provide evidence of the Brazilian economic profile.

\begin{tabular}{|l|l|l|l|l|l|}
\hline Industrial sector & Technological intensity & & & & \\
\hline & High & Medium-high & Medium-low & Low & Total \\
\hline Industrial Goods & 2 & 24 & 0 & 0 & $\mathbf{2 6}$ \\
\hline $\begin{array}{l}\text { Construction and Trans- } \\
\text { port }\end{array}$ & 0 & 0 & 5 & 0 & $\mathbf{5}$ \\
\hline Cyclical Goods & 0 & 2 & 0 & 27 & $\mathbf{2 9}$ \\
\hline Non-Cyclical Goods & 2 & 0 & 0 & 24 & $\mathbf{2 6}$ \\
\hline Basic Materials & 0 & 10 & 15 & 15 & $\mathbf{4 0}$ \\
\hline Oil, Gas and Biofuel & 0 & 0 & 4 & 0 & $\mathbf{4}$ \\
\hline IT & 3 & 0 & 0 & 0 & $\mathbf{3}$ \\
\hline Total & $\mathbf{7}$ & $\mathbf{3 6}$ & $\mathbf{2 4}$ & $\mathbf{6 6}$ & $\mathbf{1 3 3}$ \\
\hline
\end{tabular}

Table 4 - Sample technology intensity

ISSN: 07 I8-2724. (http://www.jotmi.org) 


\begin{tabular}{|c|c|c|c|c|c|c|c|c|c|c|}
\hline Indicators & $\begin{array}{l}\text { Sample } \\
\text { (I33) }\end{array}$ & $\begin{array}{l}\text { Technological } \\
\text { Intensity }\end{array}$ & Industry & & & & & & & \\
\hline & & $\begin{array}{l}\text { High (7) } \\
\text { Medium-high } \\
\text { (36) }\end{array}$ & $\begin{array}{l}\text { Medi- } \\
\text { um-low } \\
(24) \\
\text { Low (66) }\end{array}$ & $\begin{array}{l}\text { Industrial } \\
\text { Goods } \\
(26)\end{array}$ & $\begin{array}{l}\text { Construc- } \\
\text { tion and } \\
\text { Transport } \\
\text { (5) }\end{array}$ & $\begin{array}{l}\text { Cyclical } \\
\text { Goods } \\
(29)\end{array}$ & $\begin{array}{l}\text { Non-Cyclical } \\
\text { Goods (26) }\end{array}$ & $\begin{array}{l}\text { Basic } \\
\text { Materials } \\
(40)\end{array}$ & $\begin{array}{l}\text { Oil, Gas } \\
\text { and Biofu- } \\
\text { el (4) }\end{array}$ & IT (3) \\
\hline $\begin{array}{l}\text { There are R\&D } \\
\text { activities }\end{array}$ & $74 \%$ & $93 \%{ }^{\prime}$ & $66 \%$ & $92 \%$ & $40 \%$ & $55 \%$ & 77\%' & $75 \% '$ & $100 \%$ & $100 \% '$ \\
\hline $\begin{array}{l}\text { R\&D investment/ } \\
\text { Net sales ( } 3 \text { years } \\
\text { average) }\end{array}$ & $2.44 \%$ & $3.76 \%{ }^{\prime}$ & $1.25 \%$ & $2.22 \%$ & $1.25 \%$ & $2.05 \%$ & $5.96 \%{ }^{\prime}$ & $0.62 \%$ & $0.63 \%$ & $3.80 \% '$ \\
\hline Patents & 3.8 & $4.49^{\prime}$ & 3.47 & $5.46^{\prime}$ & 0.6 & 1.62 & 0.62 & 2.73 & $45^{\prime}$ & 2.67 \\
\hline $\begin{array}{l}\text { EBITDA/ Net sales } \\
\text { ( } 3 \text { years average) }\end{array}$ & $10.50 \%$ & $6.44 \%$ & $12.45 \%$ & II.82\%' & $22.47 \%^{\prime}$ & $5.49 \%$ & $0.28 \%$ & $17.74 \% '$ & |7.7I\%' & $10.25 \%$ \\
\hline $\begin{array}{l}\Delta \% \text { Net sales } \\
(2008 \text { to } 2010)\end{array}$ & $17.50 \%$ & $-0.54 \%$ & $26.18 \% '$ & $5.60 \%$ & $26.88 \%{ }^{\prime}$ & $3.85 \%$ & $60.68 \% '$ & $3.26 \%$ & $56.47 \%^{\prime}$ & $2.51 \%$ \\
\hline $\begin{array}{l}\Delta \% \text { Stock price } \\
(2008 \text { to } 2010)\end{array}$ & $84.6 \% *$ & $517.18 \% 1$ & $3,413 \% * * 1$ & $231.10 \% 1$ & $65.89 \%$ & $9,415 \% * * 1$ & $|4| .4|\%|$ & $587.56 \%$ & $70.73 \%$ & $65.12 \%$ \\
\hline
\end{tabular}

Table 5 - Technological capability and firm performance indicators, by technological intensity and industry

* Average of Bovespa Index performance.

**We used Bovespa Index as an average because prices of some shares vary greatly and deviate from the sample mean. This occurs because there are shares that have very little trade and that for some reason, when the transactions are made, they do not follow any pattern.

' Values above sample average 


\subsection{R\&D and Patenting Profile}

Among the companies that made their information about investment in research and development available $(n=38)$, the average investment in $R \& D$ represented $2.44 \%$ of net sales from 2008 to 2010. Ehie and Olibe (2010), in researching the relationship between R\&D investment and market value of U.S. industrial firms, found that the percentage invested in R\&D compared to net sales was $3.24 \%$.

Although smaller, the oil, gas and biofuel and information technology sectors are the only industries that all companies carry out R\&D activities. Also, sectors of industrial goods, non-cyclical goods and basic materials have, by percentage, more companies with R\&D in comparison with the sample. This finding is consistent with the technological intensity classification, because these are the only sectors with firms of high and medium-high-technology intensity. The exception of this information is the oil, gas and biofuel, which due to Petrobras' large size, causes a bias in the results. Although OECD (20II) classifies petroleum products as mediumlow-technology, to Brazil, this is one of the industries that leads the economy.

Patent registration was low (average of patents registered from 2008 to 2010 was 3.8 per company), and decreased during the period. Of the $133 \mathrm{firms}, 8 \mathrm{I}$ did not registered any patent in the period observed. The small number of patents reflects how little this practice is encouraged in the country. Some companies, however, stand out compared to others, such as Petrobras, which recorded $360 \%$ more patents in relation to second place in this ranking. In relation to firm performance indicators, between 2008 and 2010, the 133 firms presented an average growth of $17.5 \%$ in net sales. In relation to the number of patents registered between 2008 and 2010, the only sectors that have above average records were industrial goods and oil, gas and biofuel. The same reasoning done about Petrobras in relation to R\&D investment can be done in relation to patents registration. In the period analyzed, Petrobras have registered almost five times more patents than the second firm with the largest number of registrations, raising the average for the entire industry. Through ANOVA it was observed, with 95\% confidence interval, a significant difference regarding patent registration between industries. Oil, gas and biofuel has significant difference with every other sectors. In other words, worldwide it can be a medium-low-tech industry, but in Brazil, due to the complexity of its operation and technological requirements, it is a "cutting edge" industry.

\subsection{Performance Profile}

Considering the net sales in the last year analyzed, we highlight firms' performance of non-cyclical goods, basic materials and oil, gas and biofuel industries. Included in this list are companies such as Petrobras, Vale, Siderurgica Nacional, Usiminas, Marfrig, JBS, Gerdau, Cosan, Braskem, Arcelor and Ambev. This means that, besides Braskem (mediumhigh-technology), the highest revenues in Brazil come from low and medium-low-technology industries. Regarding the operating profit, EBITDA, industries of lower technological intensity have superior results, once again supporting the reality of an economy driven by its operational capability. Of the I 33 firms in the sample, $83(62 \%)$ had an EBITDA margin (EBITDA/net sales) above average. Of these, $66 \%$ belong to low and medium-low-technology intensity industries.

In relation to market recognition of these companies, we found that five low-tech industries had the price of their shares increased above Bovespa Index average: fabrics; agriculture; beverage, tobacco and other non-cyclical goods; personal products; and miscellaneous basic materials. Besides them, two medium-high-technology industries also grew more than average: road materials; and chemicals.

In short, the higher revenues in Brazil come from low and medium-low-technology companies and, once again, it highlights the fact that the country is focused on its operational capability. Itautec, for example, a high-tech company, which despite having invested above average in R\&D (4.13\%) and having registered more patents than average, had, in general, a below average economic performance.

These data, and the finding that sometimes those industries that have invested in their technological capabilities did not have superior economic performance, and that those industries with superior performance did not invested above average in technological capability, strengthen the characteristic of national economy. It leads to questioning the reasoning that to grow, firms must invest in technological capability.

\subsection{Technological Capability and Performance Relationship Profile}

Once we analyzed firms' technological capability and performance results, we then looked into their relationship. For that, we analyzed the data in two different ways: first, we considered nominal figures (in dollars) of investments and performance, and then we used all values adjusted for firm size. 


\subsection{I.Analysis with nominal figures}

When we look into the raw data (nominal figures) for R\&D investment of Brazilian companies, using Pearson correlation we found positive correlation $(P=0,0 I)$ between R\&D investment and patents registered. For example, correlating investments made in 2008 and patents registered in 2010, the correlation coefficient was $0.5 \mathrm{I} 3(\mathrm{p}=0,0 \mathrm{I})$. From previous works on this field, it is assumed that the larger the investments in R\&D, the more patents are registered. That is the case of Artz et al. (20I0), who tested nominal figures, found significant and positive relationship between $R \& D$ investments and the number of patents registered.

Of the sample, 99 (74.4\%) firms perform R\&D activities. From this observation, we chose to use t-test to detect differences between means of firms that have R\&D and the ones that do not. It is statistically significant $(<0.05)$ the difference between means of the two groups in relation to patents number for each year and also for total patents registered in the period. Firms with R\&D registered, on average of the period, 4.97 patents, while those that do not perform these activities, registered only 0.38 . This result confirms that companies that have research and development activities register more patents than those who do not.

This difference also occurred with respect to two indicators of economic performance, EBITDA and net sales. There was significant difference to the value of EBITDA in 2008, 2010 and the total period. The average EBITDA for the three years, for the companies that have R\&D was more than $2,000 \%$ higher than the ones without R\&D. The difference of means in relation to net sales occurred in all years of the period as well as in total period. The average net sales was $864 \%$ higher for companies carrying out R\&D activities.

Following the theory based on Schumpeter (1942), regarding the role of R\&D departments as promoters of extraordinary profits, looking into the nominal figures we could say that companies that carried out R\&D activities had superior performance.

We have also tested the correlation between investments in $R \& D$ and EBITDA. Results show significant $(p=0,0 I)$ strong to very strong correlation in all years. For the average investment between 2008 and 2010, and average EBITDA the correlation was 0,875 . Considering the correlation of the average investment with the three years average net sales, we, once again, found significant correlation $(0,740)$.

\subsubsection{Analysis with weighted data}

Correlation results become completely different when we adjusted these indicators to control for firm size.

We measured R\&D investment as the ratio of R\&D expenditure to total net sales of the firm, as it has been previously used by technological capability authors (Hall and Bagchi-Sen, 2002; Madanmohan, Kumar and Kumar, 2004; Coombs and Bierly, 2006; Ehie and Olibe, 2010). Ehie and Olibe (2010) said that it is preferable to use this measure instead of the nominal one. They claim that the latter is related to firm size and can confuse the relationship between $R \& D$ and performance.

In this sense, when we previously looked only into the nominal figures, we found that the greater the investments in R\&D were, the more these firms registered patents. However, this relationship was not sustained when controlled for the size data is analyzed. Making the analysis of the weighted data, the relationship is not significant between R\&D investment and the number of patents registered during the period $(n=38)$. If on one hand the theory shows that investment in technological capability can be translated by investments in R\&D and that, in turn, these may reflect the number of patents registered, on the other hand, the analysis showed that this relationship is weak in Brazilian firms.

We compared firms that have R\&D activities to those that do not, and analyzed their EBITDA results. When first did it with nominal figures we found significant differences between the two groups. However, when we test this same relationship, but with values weighted to company size (\% growth of EBITDA and net sales), these correlations are no longer significant. The relationship tested with nominal figures (dollars) only shows that the larger companies (higher values of EBITDA and net sales) are those that perform R\&D activities. This finding is actually stating that among the factors that influence Brazilian firms to carry out (or not) R\&D activities, is their size, because once data are controlled for the companies' size, the statistical relationship is not significant.

We have identified that firms with R\&D have recorded more patents than the ones without. They also have higher EBITDA and net sales in dollars. Since this relationship was not significant with values weighted to firm size, in the Brazilian reality, is not the fact that companies having R\&D activities lead to higher net sales and EBITDA, but rather the opposite. Large companies are those that are able to afford a R\&D department. 
Similar to what happened with EBITDA and net sales correlations with the existence of R\&D activities in the firm, happened with the other technological capability indicators: R\&D investment and patent registration. When nominal figures were analyzed, the correlations were significant and strong, however, when we attempted to control for firm size, results were rather different.

We calculated the percentage of net sales invested in R\&D, that is, the ratio of the average over the three years of investments in R\&D to the average net sales over the same period. When testing this new indicator to net sales growth of companies between 2008 and 2010, there was no significant correlation. We have also tested it with two new EBITDA indicators, to consider the size of the firms: EBITDA growth from 2008 to 20I0, and EBITDA margin (EBITDA as a percentage of net sales) of each year. While the correlations between the nominal figures of investments in R\&D and EBITDA were from strong to very strong, considering firm size we only found one significant correlation, although small $(0,328)$, and $95 \%$ significance (\% variation of EBITDA from 2008 to 2010 with R\&D investment/net sales). Additionally, there was no significant correlation between R\&D investments and net sales, when data was adjusted for firm size.

Another performance indicator analyzed was stock prices growth. There is no significant relationship between it and R\&D investments. With this finding, we note that the market is not 'recognizing' nor 'valuing' the investments in R\&D activities.

\subsubsection{The relationship between technological capability and firm performance}

Taking into account only the indicators of nominal figures, we could conclude that the more a firm invests in R\&D, the more patents it registers, and the better is its economic performance. If we take Petrobras as an example of the Brazilian scenario, we have the company with the largest revenue in dollars, the company that invests in R\&D in dollars the most, and the company that have registered the largest number of patents between 2008 and 2010 . However, all these correlations lost strength when values were controlled for the size of the firms. In this sense, confirming the findings of Griliches (1998), we understand that the true relationship should be: the larger the company, the more it is able to invest in technological capability. We have also found that, unlike the assumption that the relationship between investments in technological capability and firm performance is positive, companies with superior economic performance invested less in R\&D than the average of firms analyzed.
In sum, we could assume that, in average, big Brazilian companies do invest in R\&D and patenting. And this is boosting their performance. However, we could also state that a Brazilian company may not be big, neither invest in R\&D nor have patents and, even thought, have a positive performance.

\section{Final remarks}

Using Brazilian firms, grouped into seven different industrial sectors, we analyzed the relationship between technological capability and firm performance. By correlating indicators of both constructs, we observed that when treating data in dollars as opposed to weighted to the firm size, several relationships are significant.

The main ones are investments in R\&D with patent registration, and each one of them with EBITDA and net sales. These last two were also positive related with the existence of a R\&D area in the company. These findings could agree with the common sense that companies which have an R\&D department have higher revenue and profit, or even, the more firms invest in R\&D, the more they generate patents and the greater their revenue and profit are.

This reasoning is plausible for complex societies of developed economy. Emerging economies do not present the same characteristics, so their results are also different. Brazil is an example of this situation, a country where the industrial base consists primarily of low and medium-lowtechnology firms.

We found, at the same time, strong correlations between R\&D investments and firm performance using nominal figures, and none or very weak correlations when adjusting these figures to firm size. It shows that, in fact, the investments in technological capability are not necessarily responsible for leading Brazilian firms to achieve positive performance. Here, their size matters, the largest companies (higher net revenue) are investing more (in dollars) in R\&D and, hence, registering more patents. These results are consistent with Griliches (1998) idea, which say rich companies can spend more of their money on 'luxuries' such as R\&D. 
Besides, as it is a fact that even not investing in R\&D some companies are achieving positive results, there are other factors that are leading companies to have such performance. On average, low and medium-low-technology companies had superior results than the sample average in the performance indicators: EBITDA margin, net sales growth and growth of share price. In addition, these industries invested below average in R\&D and registered fewer patents than the sample average. However, while high and mediumhigh-technology companies invested more in R\&D and registered more patents than average, that is, they invested more in technological capability, their performance was not as remarkable as that of other sectors.

These results reflect the traditional national economic structure, which is not yet focused on technological development, but on operational capability (Zawislak et al., 20I3). In that sense, we could assume that Brazilian hightech sectors have companies labeled as such, however not behaving as high-tech ones. Once established in Brazil, they do not necessarily need to invest in high-tech capabilities. Much of the technology needed will often came from abroad, where major R\&D activities are, in fact, performed. In contrast regular local activities and learning trajectories will get concentrated mostly on operational issues. In other words, high-tech industries, differently than in developed countries, not necessarily depend on high-tech capability.

Results show that there are industries, of fundamentally lower technology intensity, which do not require investments in technological capability to achieve superior economic performance. They belong to more stable industries, focused on operational efficiency, on providing products of good quality, and on seeking the lowest possible cost. Furthermore, the operational focus stands out once again when we realized that higher revenues come from low and medium-low-technology firms, such as Petrobras, Vale and Ambev.

Considering the findings we presented, we have some concerns about the Brazilian economy future. As societies became more complex over time, emerging countries are also developing. Theory states that positive economic results are the result of investments in knowledge, in this case, technological capability. Thus, we need to discuss where, how and why to invest in research and development.
There are industries that do not depend primarily on technological development to survive, such as low-tech. The majority of investment these firms make is not on R\&D activities, but on guaranteeing that their process is in order to maintain their operational levels better than the competition's. Besides, if in Brazil there are 5.I million firms, and of that total, $98 \%$ are micro and small companies (SEBRAE, 20I2), how can we promote national technological development?

Even if the majority of the analyzed firms are of lower technology intensity, in one way or another, they maintain some kind of technological activity. Moreover, Brazil stands out worldwide in low-tech industries, such as agribusiness. Having that said, how would the relationship between technological capability and firm performance be if we observe the same industries internationally? That is, how much do the same size and sectors firms of other countries spend? If Brazil invests more in these industries than other countries, then yes, the technological capability can influence development in emerging economies. In other words, one could say that Brazilian low-tech companies, considering their internal and external competitive advantages, must behave much more as high-tech ones than Brazilian high-tech themselves.

All these findings do not diminish the merit of the firms' and the country's success. They in fact confirm a historical tradition of a country that concentrates its efforts on basic industries. Since this is a country of companies focused on operational efficiency and commercial capabilities, what types of projects can they develop without impairing their performance? Should they invest in other areas other than technological? How can we see innovation in these lowtechnology intensity industries?

Regardless of which is the 'source' of positive performance of Brazilian firms, technological or operational, any firm, to be a leader, needs to be ahead of others. That is, it must constantly change its technological content and thus, add value to shareholders.

\section{Acknowledgements}

The present study was carried out with the financial support of the Brazilian Government research funding agencies Research Foundation of the State of Rio Grande do Sul (FAPERGS) and the Brazilian National Council for Scientific and Technological Development (CNPq). 


\section{References}

ARCHIBUGI,D.;PIANTA, M. (1996). Measuring technological change though patents and innovation surveys. Technovation, I6(9), 45I-468.

ARTZ, K.; NORMAN, P.; HATFIELD, D; CARDINAL, L (20I0). A longitudinal study of the impact of R\&D, patents, and product innovation on firm performance. Journal of Product Innovation Management, 27(5), 725-740.

BELL,M.;PAVITT,K.(1995).The development of technological capabilities. In: HAQUE, I.U. (1995) Trade, Technology and International Competitiveness. Economic Development Institute of the World Bank, Washington. pp. 69-100.

BELLINGHINI, M. F.; FIGUEIREDO, P. N. (2006). Capacidades tecnológicas e estratégia empresarial: Evidências em nível de empresa da indústria de telefonia no Brasil. Revista de Administração Mackenzie, 7(2), 39-60.

BM\&FBOVESPA (2010). Setor de Atuação, Empresas Listadas. Retrieved Apr 15 20II from <http://www.bmfbovespa.com. br/Cias-Listadas/Empresas-Listadas/BuscaEmpresaListada. aspx?idioma=pt-br>.

BM\&FBOVESPA (2012). Índice Bovespa, Estatísticas históricas. Retrieved Apr 24, 2012 from <http:/l www.bmfbovespa.com.br/indices/EvolucaoMensal. aspx? Indice=lbovespa\&idioma=pt-br>.

CALANTONE, R.; CAVUSGIL, S.; ZHAO, Y. (2002). Learning orientation, form innovation capability, and firm performance. Industrial Marketing Management, 3I, 5I 5-524.

CHOI,B.;JONG,A. (2010) Assessing the impact of knowledge management strategies announcements on the market value of firms. Information and Management, 47, 42-52.

COOMBS, J. E.; BIERLY, P. E. (2006) Measuring technological capability and performance. R\&D Management, 36(4), 42I438.

DECAROLIS, D.; DEEDS, D. (1999) The impact of stocks and flows of organizational knowledge on firm performance: An empirical investigation of the biotechnology industry. Strategic Management Journal, 20, 953-968.

DEHNING, B.; RICHARDSON, V. J.; ZMUD, R. W. (2007). The financial performance effects of IT-based supply chain management systems in manufacturing firms, Journal of Operations Management, 25, 806-824.
DOSI, G. (1998) Sources, procedures, and microeconomic effects of innovation. Journal of Economic Literature, 26, II20-II7|.

EHIE, I.; OLIBE, K. (20I0). The effect of R\&D investment on firm value:An examination of US manufacturing and service industries. International Journal Production Economics, I28, 127-135.

FIGUEIREDO, P. (2009). Gestão da Inovação: conceitos, métricas e experiências de empresas no Brasil. LTC, Rio de Janeiro.

GARCÍA-MUIÑA, F.; NAVAS-LÓPEZ, J. (2007). Explaining and measuring success in new business: the effect of technological capabilities on firm results. Technovation, 27, 30-46.

GRILICHES, Z. (1998). R\&D Productivity: the econometric evidence. The University of Chicago Press, Chicago.

GUAN, J.; YAM, R.; MOK, C.; MA, N. (2006). A study of the relationship between competitiveness and technological innovation capability based on DEA models. European Journal of Operational Research, 170, 97I-986.

HAIR, J.; BABIN, B.; MONEY, A.; SAMOUEL, P. (2005). Fundamentos de métodos de pesquisa em administração. Bookman, Porto Alegre.

HALL, L.;BAGCHI-SEN,S. (2002).A study of R\&D, innovation, and business performance in the Canadian biotechnology industry.Technovation, 22, 23I-244.

INPI - Instituto Nacional da Propriedade Intelectual (20I I). Consulta à Base de Patentes do INPI. Retrieved Nov. and Dec. 0I, 20I I from <http://pesquisa.inpi.gov.br/MarcaPatente/jsp/ servimg/validamagic.jsp?BasePesquisa=Patentes $>$.

ISOBE, T.; MAKINO, S.; MONTGOMERY, D. (2008). Technological capabilities, and firm performance: The case of small manufacturing firms in Japan. Asia Pacific Journal of Management, 25, 4I3-428.

JIN, J.; VON ZEDTWITZ, M. (2008) Technological capability development in China's mobile phone industry.Technovation, 28, 327-334.

KIM, L. (1999). Building technological capability for industrialization: analytical frameworks and Korea's experience. Industrial and Corporate Change, 8( $\mathrm{I}), \mathrm{I} \mathrm{I}-\mathrm{I} 36$. LALL,S.(1992).Technological capabilities and industrialization. World Development, 20(2), 165-186. 
MADANMOHAN, T.; KUMAR, U.; KUMAR, V. (2004). Import-led technological capability: a comparative analysis of Indian and Indonesian manufacturing firms. Technovation, 24, 979-993.

NELSON, R.; WINTER, S. (2005). Uma teoria evolucionária da mudança econômica. UNICAMP, Campinas.

OECD (2005). Directorate for Science, Technology and Industry. Stan Indicators (2005 edition).

OECD (20II). Technology intensity definition. ISIC rev. 3. Retrieved Apr 01, 2012 from

< http://www.oecd.org/dataoecd/43/4I/4835023 I.pdf>.

PANDA, H.; RAMANATHAN, K. (2006). Technological capability assessment of a firm in the electricity sector. Technovation, I6(I0), 56I-588.

PAVITT, K. (1998). Technologies, products and organization in the innovating firm: what Adam Smith tells us and Joseph Schumpeter doesn't. Industrial and Corporate Change, 7(3), 433-452.

RUFFONI, J.; STEFFANELLO, M.; REICHERT, F.; DE ROSSI, G.; PUFAL, N. (20I2, August). Footwear industry innovation capability: Southern Brazilian evidence. Academy of Management Annual Meeting, Boston, I-32.

SCHUMPETER, J. ([I9II] 2008a). The Theory of Economic Development. Transaction, New Jersey.

SCHUMPETER, ]. ([1942] 2008b). Capitalism, Socialism and Democracy. Harper Perennial Modern Thought, New York

SEBRAE. Retrieved May 0I, 2012 from <http://www. sebraesp.com.br/TenhoUmaEmpresa/Biblioteca/ OutrosConteudos/EstudosEPesquisas/MPEsEmNumeros/ Paginas/MPEsEmNumeros.aspx>, 2012.

SIRMON, D.; HITT, M.; IRELAND, R. (2007) Managing firm resources in dynamic environments to create value: looking inside the black box.Academy of Management Review, 32(I), 273-292.

TEECE, D. (1986). Profiting from technological innovation: implications for integration, collaboration, licensing and public policy. Research Policy, 15, 285-305.

TIGRE, P. A. (1998). Inovação e teorias da firma em três paradigmas. Revista de Economia Contemporânea, 3, 67-III.
TSAI, K. (2004). The impact of technological capability on firm performance in Taiwan's electronics industry. Journal of High Technology Management Research, 15, 183-195.

WANG, E. (2007). R\&D efficiency and economic performance: A cross-country analysis using the stochastic frontier approach. Journal of Policy Modeling, 29, 345-360.

YAM, R.; GUAN, J.; PUN, K.; TANG, E. (2004). An audit of technological innovation capabilities in Chinese firms: some empirical findings in Beijing, China. Research Policy, 33, I I 23II40.

ZAWISLAK, P.;ALVES,A.;TELLO-GAMARRA, J.; BARBIEUX, D.; REICHERT, F. (20I2). Innovation capability: from technology development to transaction capability. Journal of Technology Management and Innovation, 7(2), 14-27.

ZAWISLAK, P.A., ZEN, A. C., FRACASSO, E. M., REICHERT, F. M. and PUFAL, N. A. (20I3). Types of innovation in lowtechnology firms of emerging markets: an empirical study in Brazilian Industry. Revista de Administração e Inovação, $10(I), 2 \mid 2-23 I$. 


\section{Appendix I - Industrial sector classification}

\begin{tabular}{|c|c|c|}
\hline Classification & Detailed classification & Quantity \\
\hline \multirow[t]{8}{*}{ Industrial Goods } & Industrial Goods / Electrical equipment / Electrical equipment & 1 \\
\hline & Goods / Ind. machinery and equip/ Machinery and equip, constr. and agricultural & I \\
\hline & Goods / Industrial machinery and equipment / Motors, compressors and other & 3 \\
\hline & Goods / Industrial machinery and equipment / Weapons and ammunition & I \\
\hline & Goods / Industrial machinery and equipment / Machinery and hospital equipment & $\mathrm{I}$ \\
\hline & Goods / Industrial machinery and equipment / Industrial equipment and supplies & 4 \\
\hline & Industrial Goods / Vehicles / Aircraft material & I \\
\hline & Industrial Goods / Vehicles / Material road & 13 \\
\hline Constr. and Transp. & $\begin{array}{l}\text { Construction and transportation / Engineering and construction / Building mate- } \\
\text { rials }\end{array}$ & 5 \\
\hline \multirow[t]{8}{*}{ Cyclical Goods } & Cyclical goods / Leisure / Bicycles & 2 \\
\hline & Cyclical goods / Leisure / Toys and games & 2 \\
\hline & Cyclical goods / Textiles, apparel and footwear / Accessories & 1 \\
\hline & Cyclical goods / Textiles, apparel and footwear /Footwear & 4 \\
\hline & Cyclical goods / Textiles, apparel and footwear /Fabric & 15 \\
\hline & Cyclical goods / Textiles, apparel and footwear /Apparel & 2 \\
\hline & Cyclical goods / Housewares / Appliances & 2 \\
\hline & Cyclical goods / Housewares /Housewares & 1 \\
\hline Non-Cyclical Goods & Non-cyclical goods / Farming / Agriculture & 3 \\
\hline
\end{tabular}




\begin{tabular}{|c|c|c|}
\hline & Non-cyclical goods / Processed foods / Sugar and alcohol & 3 \\
\hline & Non-cyclical goods / Processed foods / Various food & 4 \\
\hline & Non-cyclical goods / Processed foods /Coffee & 3 \\
\hline & Non-cyclical goods / Processed foods / Meat and meat products & 5 \\
\hline & Non-cyclical goods / Processed foods / Grains and grain products & I \\
\hline & Non-cyclical goods / Beverages / Beer and soft drinks & I \\
\hline & Non-cyclical goods / Miscellaneous / Miscellaneous Products & I \\
\hline & Non-cyclical goods / Tobacco / Cigarettes and tobacco & 1 \\
\hline & Non-cyclical goods / Personal care products / Cleaning & 1 \\
\hline & Non-cyclical goods / Personal care products /Personal care & I \\
\hline & Non-cyclical goods / Health / Medications and other products & 2 \\
\hline \multirow[t]{11}{*}{ Basic Materials } & Basic materials / Packaging / Packaging & 4 \\
\hline & Basic materials / Wood and paper / Wood & 2 \\
\hline & Basic materials / Wood and paper / Pulp and paper & 6 \\
\hline & Basic materials / Miscellaneous / Miscellaneous & 3 \\
\hline & Basic Materials / Mining / Minerals metal & 2 \\
\hline & Basic Materials / Chemicals / Fertilizers and pesticides & 4 \\
\hline & Basic Materials / Chemicals / Petrochemicals & 5 \\
\hline & Basic Materials / Chemicals / Chemical diverse & I \\
\hline & Basic materials / Metallurgy and steel / Copper artifacts & I \\
\hline & Basic materials / Metallurgy and steel / Iron and steel artifacts & 7 \\
\hline & Basic materials / Metallurgy and steel / Steel & 5 \\
\hline Oil, Gas and Biofuel & Oil, gas and biofuel / Oil, gas and biofuel / Exploration or refining & 4 \\
\hline IT & Information technology / Computers and equipment / Computers and equipment & 3 \\
\hline
\end{tabular}

